\title{
High-resolution records of the beryllium-10 solar activity proxy in ice from Law Dome, East Antarctica: measurement, reproducibility and principal trends
}

\author{
J. B. Pedro ${ }^{1,2}$, A. M. Smith ${ }^{3}$, K. J. Simon ${ }^{3}$, T. D. van Ommen ${ }^{2,4}$, and M. A. J. Curran ${ }^{2,4}$ \\ ${ }^{1}$ Institute of Marine and Antarctic Studies, University of Tasmania, Hobart, TAS, Australia \\ ${ }^{2}$ Antarctic Climate and Ecosystems Cooperative Research Centre, Hobart, TAS, Australia \\ ${ }^{3}$ Australian Nuclear Science and Technology Organisation, Menai, NSW, Australia \\ ${ }^{4}$ Australian Antarctic Division, Kingston, TAS, Australia
}

Received: 13 February 2011 - Published in Clim. Past Discuss.: 22 February 2011

Revised: 21 May 2011 - Accepted: 14 June 2011 - Published: 12 July 2011

\begin{abstract}
Three near-monthly resolution ${ }^{10} \mathrm{Be}$ records are presented from the Dome Summit South (DSS) ice core site, Law Dome, East Antarctica. The chemical preparation and Accelerator Mass Spectrometer (AMS) measurement of these records is described. The reproducibility of ${ }^{10} \mathrm{Be}$ records at DSS is assessed through intercomparison of the ice core data with data from two previously published and contemporaneous snow pits. We find generally good agreement between the five records, comparable to that observed between other trace chemical records from the site. This result allays concerns raised by a previous Antarctic study (Moraal et al., 2005) about poor reproducibility of ice core ${ }^{10} \mathrm{Be}$ records. A single composite series is constructed from the three ice cores providing a monthly-resolved record of ${ }^{10} \mathrm{Be}$ concentrations at DSS over the past decade (1999 to 2009). To our knowledge, this is the first published ice core data spanning the recent exceptional solar minimum of solar cycle $23 .{ }^{10} \mathrm{Be}$ concentrations are significantly correlated to the cosmic ray flux recorded by the McMurdo neutron monitor $\left(r_{\mathrm{xy}}=0.64\right.$, with $95 \% \mathrm{CI}$ of 0.53 to 0.71$)$, suggesting that solar modulation of the atmospheric production rate may explain up to $\sim 40 \%$ of the variance in ${ }^{10} \mathrm{Be}$ concentrations at DSS. Sharp concentration peaks occur in most years during the summer-to-autumn, possibly caused by stratospheric incursions. Our results underscore the presence of both production and meteorological signals in ice core ${ }^{10} \mathrm{Be}$ data.
\end{abstract}

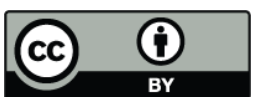

Correspondence to: J. B. Pedro (jbpedro@utas.edu.au)

\section{Introduction}

Atmospheric cosmogenic beryllium-10 $\left({ }^{10} \mathrm{Be}\right)$ in polar ice is an important proxy for past variations in solar activity and cosmic ray intensity (Bard et al., 2000; McCracken et al., 2004; Vonmoos et al., 2006; Steinhilber et al., 2009). Ice core ${ }^{10} \mathrm{Be}$ records, therefore, offer great potential for use in refining our understanding of links between solar activity and climate. However, obtaining reliable information from the ${ }^{10} \mathrm{Be}$ record requires proven sample processing and measurement techniques, along with a good understanding of the sequence of environmental processes controlling production in the atmosphere and ultimate storage in the ice sheet. We have developed a methodology for accurate measurement of high-resolution, precisely-dated ice core and snow pit ${ }^{10} \mathrm{Be}$ records that can be used to improve understanding of environmental influences on ${ }^{10} \mathrm{Be}$ concentrations in ice.

${ }^{10} \mathrm{Be}$ (half-life, $(1.36 \pm 0.07) \times 10^{6} \mathrm{yr}$ (Nishiizumi et al., 2007)) is produced in the lower stratosphere and troposphere by the spallation of $\mathrm{N}$ and $\mathrm{O}$ atoms by galactic cosmic rays (GCR) (Lal and Peters, 1967). Variations in the solar magnetic field modulate the GCR flux and, therefore, the atmospheric production rate of ${ }^{10} \mathrm{Be}$. Variations in the solar magnetic field are also correlated to variations in solar irradiance; it is this relation that is the basis for using long-term variations in ${ }^{10} \mathrm{Be}$ concentrations in polar ice as proxy records of past solar irradiance (Beer, 2000). Additionally, the terrestrial magnetic field also modulates the GCR, however, this occurs mainly over centennial to millennial timescales (Muscheler et al., 2007) that are outside the scope of the present study.

Published by Copernicus Publications on behalf of the European Geosciences Union. 
The challenge of measuring the extremely low concentrations of ${ }^{10} \mathrm{Be}$ in polar ice (of order $10^{4}$ atoms $\mathrm{g}^{-1}$ ) was met by Accelerator Mass Spectrometry (AMS) techniques developed in the 1970s (e.g. Raisbeck et al., 1978). ${ }^{10} \mathrm{Be}$ records have now been produced from multiple polar ice core sites, in both Greenland (e.g., Dye 3, GRIP, GISP2, Renland (Beer et al., 1990, 1991; Yiou et al., 1997; Finkel and Nishiizumi, 1997; Aldahan et al., 1998; Heikkilä et al., 2008b)) and Antarctica (e.g., Dome Concordia, South Pole, Dome Fuji, Taylor Dome, Queen Maud Land, Dronning Maud Land and Law Dome (Raisbeck et al., 1990; Steig et al., 1996; Aldahan et al., 1998; Smith et al., 2000; Moraal et al., 2005; Pedro et al., 2006; Horiuchi et al., 2008; Pedro et al., 2009)). Particular care in sample preparation and measurement is required for samples from Law Dome, where ${ }^{10} \mathrm{Be}$ concentrations are the lowest of all of these sites. A major challenge to the sensitivity of AMS measurement of ${ }^{10} \mathrm{Be}$ is interference from the isobar boron $\left({ }^{10} \mathrm{~B}\right)$ (e.g. Aldahan et al., 1998; Pedro et al., 2009). To this end, our previous sample processing technique (Child et al., 2000) has been modified by introducing several steps aimed at reducing the levels of ${ }^{10} \mathrm{~B}$ in samples.

Following measurement, a number of factors complicate the interpretation of the ${ }^{10} \mathrm{Be}$ record. One of these, which is a potential issue hindering the interpretation of all ice core trace chemicals, is the physical reworking or chemical alteration of the snow pack after deposition (Wolff, 1996). This may occur, for example, by removal, re-deposition and/or mixing of near-surface snow by the wind, ablation, melt, sublimation or post-depositional chemical exchange between the atmosphere and ice (Jones et al., 2009). Recently, questions have been raised about the potential for significant post-depositional influences on ${ }^{10} \mathrm{Be}$ in a study that found up to fourfold differences in ${ }^{10} \mathrm{Be}$ concentrations between two records extracted from the Queen Maud Land Ice Shelf (Moraal et al., 2005). The cause of this discrepancy was not resolved, however, it was proposed that local scale and/or post-depositional factors were involved. This study, although not carried out at a proven ice core site, has contributed to concern about the reliability of ice core records of ${ }^{10} \mathrm{Be}$ more generally (e.g. Webber and Higbie, 2010). Such concerns need to be resolved before historical ${ }^{10} \mathrm{Be}$ records can be confidently used to infer past variations in solar activity or cosmic ray intensity (Webber and Higbie, 2010). Addressing this issue, i.e., the reproducibility of ${ }^{10} \mathrm{Be}$ records, requires multiple ice cores from nearby locations. However, with the exception of the Moraal et al. (2005) study, multiple records from individual Antarctic or Greenland ice core sites have not previously been available. This has been a motivation for high-resolution study of ${ }^{10} \mathrm{Be}$ deposition at the Law Dome ice core site.

A second motivation for accessing high-resolution and well dated ${ }^{10} \mathrm{Be}$ records is to directly test the response of ${ }^{10} \mathrm{Be}$ concentrations in ice to variations in the atmospheric production rate. The parameter most suited to conducting such tests is the GCR flux recorded by ground-based neutron monitors. Neutron monitors provide a precise and high time resolution measure of the GCR that is linearly related to the ${ }^{10} \mathrm{Be}$ production rate at any point in the Earth's atmosphere (O'Brien and Burke, 1973). By contrast, the sunspot record is less useful since the relation between sunspots and ${ }^{10} \mathrm{Be}$ production is neither linear nor direct (Lean et al., 2002; McCracken et al., 2004). Previously, testing the relation between ${ }^{10} \mathrm{Be}$ and the GCR has been limited by a scarcity of ${ }^{10} \mathrm{Be}$ records that are contemporaneous with the era of neutron monitor measurements beginning in the 1950s. Of the handful of comparisons that have been made (Taylor Dome Antarctica (Steig et al., 1996), Queen Maud Land Antarctica (Moraal et al., 2005), GRIP and DYE3, Greenland (Berggren et al., 2009) and Renland, Greenland (Aldahan et al., 1998)), in all cases, trends in ${ }^{10} \mathrm{Be}$ data consistent with the 11-yr Schwabe cycle modulation of the atmospheric production rate are observed. However, each site is also affected by environmental factors unrelated to atmospheric production (Field and Schmidt, 2009; Webber and Higbie, 2010). Constraining the strength of the production rate signal at Law Dome, and hence the sites suitability for obtaining a long-term record of past solar activity, is an objective of the present study.

Distinguishing our work from studies at other sites is the near-monthly resolution of the Law Dome data, compared to annual and coarser at the other sites. This high resolution, combined with accurate dating also permits the investigation of short-term (monthly to seasonal) variations in ${ }^{10} \mathrm{Be}$ concentrations and their possible causes.

\section{Methods}

\subsection{The Law Dome ice core site}

Law Dome is a small ( $200 \mathrm{~km}$ diameter) ice cap, situated in Wilkes Land, Coastal East Antarctica (Fig. 1). The icecap is separated from the flow of the main East Antarctic ice sheet and is the most northerly point on the Antarctic coast outside the Antarctic Peninsula (Morgan et al., 1997). The passage of cyclonic systems originating to the north combined with the polar easterlies and the orographic influence of Law Dome, produces exceptionally high accumulation, which is relatively uniformly distributed throughout the year with respect to other deep Antarctic ice core sites (van Ommen and Morgan, 1997).

The high accumulation rate at DSS $\left(0.68 \mathrm{~m} \mathrm{yr}^{-1}\right.$ ice equivalent), coupled with low annual mean wind-speed $\left(8.3 \mathrm{~m} \mathrm{~s}^{-1}\right)$ and perennially low temperatures (summer mean: $-12.6^{\circ} \mathrm{C}$ ) (Morgan et al., 1997) results in the preservation of unambiguous annual snow layers. These thick annual layers can be reliably detected using a variety of measurement techniques and counted to produce accurate dating (Sect. 2.5). Hence, ice core and snow pit records from DSS are particulary suited to investigating annual to sub-annual variations in the trace 


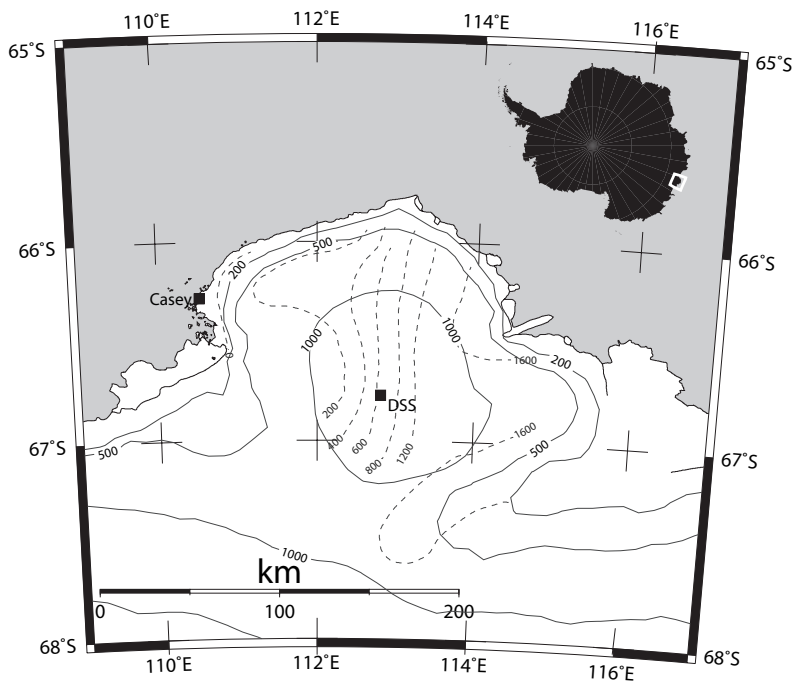

Fig. 1. Location of the Dome Summit South (DSS) sample site, Law Dome with surface elevation contours ( $m$, solid lines) and accumulation isopleths ( $\mathrm{mm}$ ice equivalent, dashed lines).

chemical concentrations of snow and this has been a focus of prior glaciological work at the site e.g., (van Ommen and Morgan, 1997; Curran et al., 1998; Palmer et al., 2001).

The ${ }^{10} \mathrm{Be}$ records discussed here were taken from close to the Dome Summit South ice core drilling site (DSS: $66^{\circ} 46^{\prime} \mathrm{S}$ $\left.112^{\circ} 48^{\prime} \mathrm{E}\right), 4.6 \mathrm{~km}$ south-southwest from the summit of the Dome (Fig. 1).

\subsection{Law Dome ${ }^{10} \mathrm{Be}$ records}

Three new ${ }^{10} \mathrm{Be}$ ice core records (total of 117 samples) from the DSS site, sampled at near-monthly resolution, are presented here: DSS0506-core, DSS0809-core and DSS0910core. These new records are also compared with two previously published snow pit records: DSS0102-pit and DSS0506-pit (for sampling details refer to Pedro et al., 2006, 2009). The names of the records refer to the sample site ("DSS") followed by the (austral) summer during which sampling took place (e.g., "0506" refers to summer of 2005 to 2006).

DSS0506-core was drilled using a $195 \mathrm{~mm}$ diameter thermal drill (see also Burn-Nunes et al., 2011), whilst DSS0809 and DSS0910-core were drilled using $79 \mathrm{~mm}$ diameter Polar Ice Core Office (PICO) hand augers. Three PICO cores were drilled alongside each other in order to obtain sufficient mass for ${ }^{10} \mathrm{Be}$ measurements. A summary of the key details of each ${ }^{10} \mathrm{Be}$ record discussed in the text is provided in Table 1.

\subsection{Sample preparation}

${ }^{10} \mathrm{Be}$ samples were cut from the ice cores continuously at the depth intervals listed in Table 1. For the PICO cores, ice from the three adjacent cores was combined into one sample. Sample masses ranged between 0.5 to $2.0 \mathrm{~kg}$. All work took place in a HEPA-filtered cold laboratory using a stainless steel band-saw.

Detailed stable water isotope $\left(\delta^{18} \mathrm{O}\right)$ and trace chemical records were also extracted from the cores at high resolution (ranging from 3.0 to $6.0 \mathrm{~cm}$ ). For $\delta^{18} \mathrm{O}$ measurements, sub-samples $(0.4 \mathrm{ml})$ were equilibrated with $\mathrm{CO}_{2}$ at $25^{\circ} \mathrm{C}$ with a VG Isoprep-18 equilibration bench. $\delta^{18} \mathrm{O}$ ratios of the equilibrated $\mathrm{CO}_{2}$ were measured on a VG Isogas SIRA mass spectrometer at the Central Science Laboratory, University of Tasmania. The $\delta^{18} \mathrm{O}$ values are expressed as per mil $(\% o)$ with respect to Vienna Standard Mean Oceanic Water (V-SMOW). Standard deviation of the $\delta^{18} \mathrm{O}$ values for repeated measurements of laboratory reference water samples was less than $0.07 \%$. Trace chemical measurements were performed by suppressed ion chromatography following previous techniques (Curran and Palmer, 2001).

\subsection{Extraction of ${ }^{10} \mathrm{Be}$ from ice and AMS measurement}

A flow chart depicting the procedure for preparing ${ }^{10} \mathrm{Be}$ samples for Accelerator Mass Spectrometer (AMS) measurement is shown in Fig. 2. This updated procedure, which was used on the DSS0506-core, DSS0809-core and DSS0910core, is based on the methods for extraction of ${ }^{10} \mathrm{Be}$ from aqueous samples described by Child et al. (2000) and Smith et al. (2000), with recent revisions aimed at improving efficiency and reducing levels of the isobaric AMS interferant boron.

All equipment was rinsed with dilute $\mathrm{HNO}_{3}$ solution and then triple rinsed with deionised water $\left(18 \Omega \mathrm{cm}^{-1}\right.$ resistivity). Ice samples were melted inside a covered polypropylene container in the presence of $\sim 0.26 \mathrm{~g}$ of $(1.090 \pm 0.020) \times$ $10^{3} \mathrm{mg} \mathrm{kg}^{-1}$ accurately weighed ${ }^{9} \mathrm{Be}$ carrier solution, prepared from the mineral beryl with a ${ }^{10} \mathrm{Be}:{ }^{9} \mathrm{Be}$ ratio of $<$ $3 \times 10^{15}$. The absolute ${ }^{9} \mathrm{Be}$ concentration of the carrier was verified by inductively coupled plasma atomic emission spectroscopy. Due to the acidity of the carrier (it was prepared in dilute $\mathrm{HNO}_{3}$ ) the samples typically had a $\mathrm{pH}$ of $\sim 4.2$ after melting. A complementary set of $\delta^{18} \mathrm{O}$ samples (in addition to those taken directly from the cores, Sect. 2.3) were taken from the bulk meltwater of each ${ }^{10} \mathrm{Be}$ sample. These $\delta^{18} \mathrm{O}$ measurements provide a record that is directly co-registered with the ${ }^{10} \mathrm{Be}$ record. For each set of ten ice samples a ${ }^{10} \mathrm{Be}$ chemistry blank sample was also prepared by adding carrier to deionised water and thereafter treating identically as for samples.

Sample meltwater was peristaltically-pumped through $41 \mu \mathrm{m}$ (nylon) and $0.45 \mu \mathrm{m}$ (nitrocellulose) in-series filters directly into columns containing $10 \mathrm{ml}$ of cleaned and conditioned (see Fig. 2) Dowex 50W-X8 200 mesh cation exchange resin, which captures beryllium. The $41 \mu \mathrm{m}$ filter removes micro-meteorites and other foreign matter, while the 
Table 1. Details of the high-resolution DSS, Law Dome ${ }^{10} \mathrm{Be}$ snow pit and ice core records discussed in the text.

\begin{tabular}{|c|c|c|c|c|c|}
\hline${ }^{10} \mathrm{Be}$ record (sample method) & Location & Samples & $\begin{array}{c}\text { Resolution } \\
\text { (metres, months) }\end{array}$ & Period spanned & $\begin{array}{l}\text { Mean }\left[{ }^{10} \mathrm{Be}\right] \pm 1 \sigma \\
\left(\times 10^{3} \text { atoms } \mathrm{g}^{-1}\right)\end{array}$ \\
\hline DSS0102-pit (snow pit) & $\begin{array}{r}66^{\circ} 46^{\prime} 09^{\prime \prime} \mathrm{S} \\
112^{\circ} 48^{\prime} 38^{\prime \prime} \mathrm{E}\end{array}$ & 20 & $0.10,0.57$ & $\begin{array}{l}\text { Jan 2001- } \\
\text { Dec 2001 }\end{array}$ & $5.00 \pm 1.91$ \\
\hline DSS0506-pit (snow pit) & $\begin{array}{r}66^{\circ} 46^{\prime} 11^{\prime \prime} \mathrm{S} \\
112^{\circ} 48^{\prime} 41^{\prime \prime} \mathrm{E}\end{array}$ & 40 & $0.10,0.78$ & $\begin{array}{l}\text { Mar 2004- } \\
\text { Oct } 2005\end{array}$ & $5.52 \pm 1.77$ \\
\hline DSS0506-core (thermal core) & $\begin{array}{r}66^{\circ} 46^{\prime} 20^{\prime \prime} \mathrm{S} \\
112^{\circ} 48^{\prime} 26^{\prime \prime} \mathrm{E}\end{array}$ & 62 & $0.13,1.07$ & $\begin{array}{l}\text { Dec 1999- } \\
\text { Jun } 2005\end{array}$ & $4.61 \pm 1.43$ \\
\hline DSS0809-core (PICO core) & $\begin{array}{r}66^{\circ} 46^{\prime} 02^{\prime \prime} \mathrm{S} \\
112^{\circ} 48^{\prime} 28^{\prime \prime} \mathrm{E}\end{array}$ & 40 & $0.14,1.25$ & $\begin{array}{l}\text { Dec 2004- } \\
\text { Dec } 2008\end{array}$ & $7.58 \pm 1.94$ \\
\hline DSS0910-core (PICO core) & $\begin{array}{r}66^{\circ} 46^{\prime} 02^{\prime \prime} \mathrm{S} \\
112^{\circ} 48^{\prime} 28^{\prime \prime} \mathrm{E}\end{array}$ & 15 & $0.14,0.93$ & $\begin{array}{l}\text { Oct 2008- } \\
\text { Dec } 2009\end{array}$ & $6.74 \pm 2.31$ \\
\hline Full chemistry blanks & NA & 16 & NA & NA & $0.06 \pm 0.04$ \\
\hline
\end{tabular}

$0.45 \mu \mathrm{m}$ filter removes terrestrial dust, both of which contain ${ }^{10} \mathrm{Be}$ at concentrations several orders of magnitude higher than those occurring naturally in Antarctic ice (Baumgartner et al., 1997). Beryllium was stripped from the columns by a sequence of three washes of $20 \mathrm{ml}, 15 \mathrm{ml}$ and $20 \mathrm{ml}$ of $3 \mathrm{MHNO}_{3}$. Eluent from the first two washes was combined into a single fraction and then $\mathrm{pH}$ adjusted to 7.8 to 8.5 by adding concentrated $\mathrm{NH}_{3}$. Full precipitation of beryllium (as $\mathrm{Be}(\mathrm{OH})_{2}$ ) was achieved after several hours, whereupon the sample was centrifuged and the supernatant discarded. Typically all beryllium was stripped from the column by the first fraction and neutralisation of the eluent from the final $20 \mathrm{ml}$ "backup" fraction did not yield any precipitate. The $\mathrm{Be}(\mathrm{OH})_{2}$ was dissolved in $\sim 1 \mathrm{ml} 1 \mathrm{MHNO}_{3}$ then treated to remove boron by adding $2 \mathrm{ml}$ concentrated $\mathrm{H}_{2} \mathrm{SO}_{4}$ and $5 \mathrm{ml}$ of concentrated $\mathrm{HF}$ and heating to reduce the volume to $2 \mathrm{ml}$ in a teflon beaker ("fuming"). This treatment volatalises the boron present in the sample as $\mathrm{BF}_{3}$ (boiling point $101^{\circ} \mathrm{C}$ ). After cooling, a further $5 \mathrm{ml}$ of concentrated HF was added and the fuming process was repeated. As the presence of fluorides in the sample will affect the chemical equilibria of $\mathrm{Be}$ cations in solution (Child et al., 2000), the sample was heated for a further hour to ensure complete removal of HF. When treated in this way, ${ }^{10} \mathrm{Be}$ measurements have been completed on samples which were previously unmeasurable on the Australian National Tandem for Applied Research (ANTARES) AMS due to their high boron levels (Simon et al., 2011).

$\mathrm{Be}(\mathrm{OH})_{2}$ was then precipitated by adjusting the sample $\mathrm{pH}$ to 7.8 to 8.5 using concentrated $\mathrm{NH}_{3}$ and again collected by centrifuging. In a further step aimed at removing any boron hydroxides (which in contrast to $\mathrm{Be}(\mathrm{OH})_{2}$ remain soluble at neutral pH Child et al., 2000), the $\mathrm{Be}(\mathrm{OH})_{2}$ was dissolved in several drops of $1 \mathrm{MHNO}_{3}$, re-precipitated by neutralisation with $1 \mathrm{MNH}_{3}$, rinsed with deionised water and centrifuged discarding the supernatant to waste (with this sequence being repeated two more times in order to thoroughly clean the $\mathrm{Be}(\mathrm{OH})_{2}$ of soluble boron hydroxides). After dry- ing at $60^{\circ} \mathrm{C}$, the $\mathrm{Be}(\mathrm{OH})_{2}$ was calcined at $800^{\circ} \mathrm{C}$ for $6 \mathrm{~h}$ in a quartz crucible to $\mathrm{BeO}$. Median carrier recovery yield was $70 \%$, with the majority of the loss associated with the acid wash step rather than the fuming step. Finally, the $\mathrm{BeO}$ was mixed with 325 mesh niobium powder in an agate pestle and mortar at a mass ratio of $\sim 1: 4 \mathrm{BeO}: \mathrm{Nb}$. The mixture was loaded into $1.6 \mathrm{~mm}$-diameter aluminium target holders and rear-pressed at a pressure of $120 \mathrm{kPa}$ against a steel pin. This provides a good quality sample surface at a reproducible depth below the target face.

Measurement of the three ice core ${ }^{10} \mathrm{Be}$ records was carried out using the ANTARES AMS facility at ANSTO, following the basic method outlined in Fink et al. (2000). $\mathrm{BeO}^{-}$ was injected with a terminal voltage of $6.880 \mathrm{MV}$ and the $3+$ charge state was selected, with ${ }^{9} \mathrm{Be}^{3+}$ currents of 2 to $6 \mu \mathrm{A}$ and a particle transmission of $\sim 36 \%$ from the entrance of the accelerator to the detector. Fast isotope cycling was used to inject ${ }^{9} \mathrm{Be}^{16} \mathrm{O}^{-}$(1 ms) followed by ${ }^{10} \mathrm{Be}^{16} \mathrm{O}^{-}$(199 ms) for a repetition rate of $5 \mathrm{~Hz}$. Samples were moved in a circular path under the primary cesium beam to minimise sample cratering and to maximise the use of sample material. The measurement proceeded by bracketing four ice samples between reference standards with measurement times of $600 \mathrm{~s}$ for the samples and $120 \mathrm{~s}$ for the standards. All ice samples were measured twice, but where necessary some were measured for a third time to obtain $\sim 2.5 \%$ precision. The standards (typically 5) were cycled throughout the run.

All measurements were normalised to the National Institute of Standards ${ }^{10} \mathrm{Be}$ standard reference material 4325 (NIST SRM), utilising the Nishiizumi et al. $(2007){ }^{10} \mathrm{Be}:{ }^{9} \mathrm{Be}$ ratio of $(2.79 \pm 0.02) \times 10^{-11}$. Measurements of the NIST SRM exhibited standard deviation of $<2 \% .{ }^{10} \mathrm{Be}:{ }^{9} \mathrm{Be}$ ratios for samples prepared from ice ranged from (234 to 992$) \times$ $10^{-15}$. Chemistry procedural blanks had consistently low ${ }^{10} \mathrm{Be}:{ }^{9} \mathrm{Be}$ ratios. The mean for all blanks $( \pm 1 \sigma)$ was $(3.1 \pm$ 1.4) $\times 10^{-15}$. The extremely low chemistry blank values demonstrate that the ${ }^{9} \mathrm{Be}$ carrier, chemistry processes and 


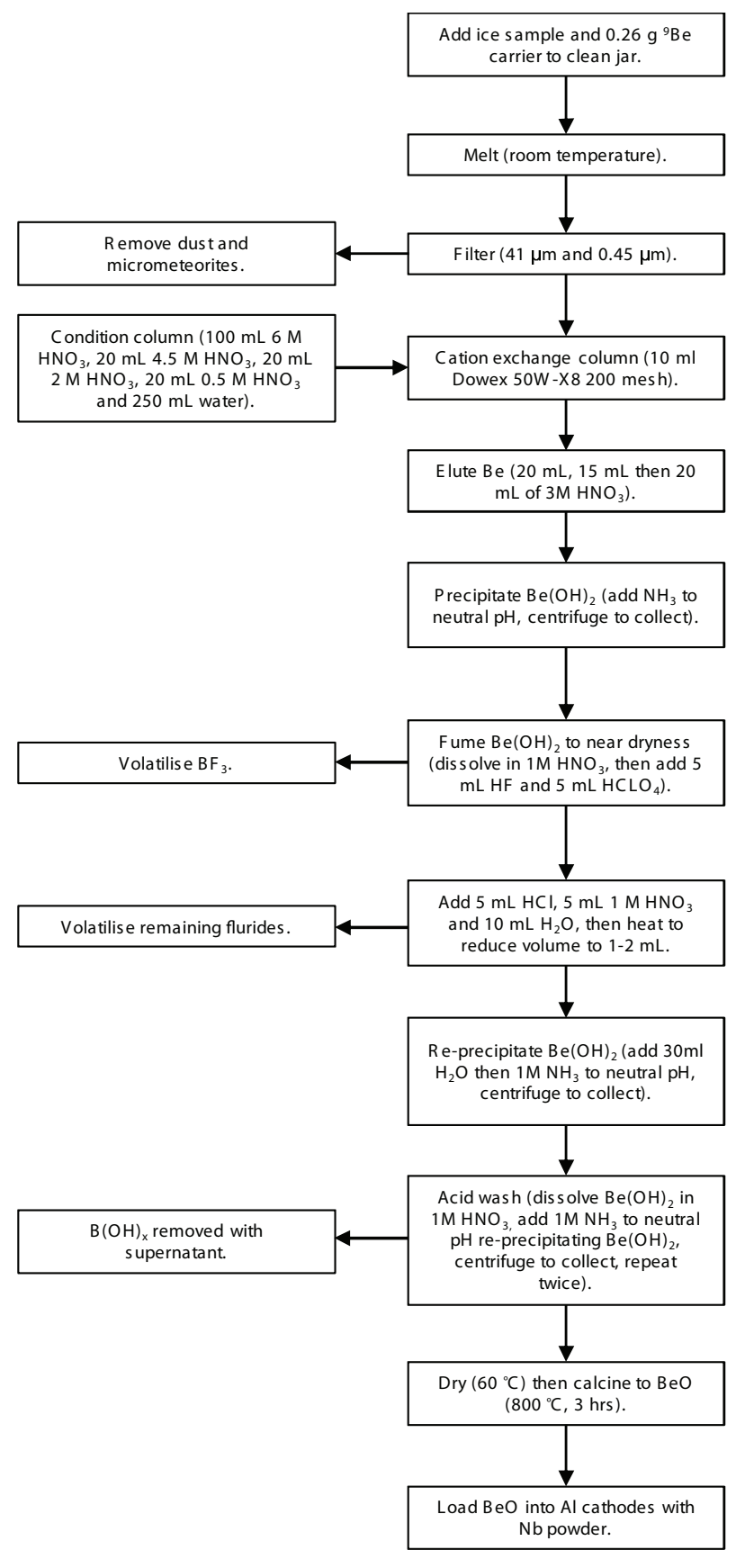

Fig. 2. Flowchart showing the procedure used for extracting ${ }^{10} \mathrm{Be}$ from ice samples for AMS measurement.

machine background did not introduce ${ }^{10} \mathrm{Be}$ at any significant level. Boron $\left({ }^{10} \mathrm{~B}^{3+}\right)$ rates were sufficiently low that there was no interference with the measurement of ${ }^{10} \mathrm{Be}^{3+}$.

Knowing the quantity of ${ }^{9} \mathrm{Be}$ carrier added initially, the ${ }^{10} \mathrm{Be}:{ }^{9} \mathrm{Be}$ ratio is used to directly obtain the number of atoms of ${ }^{10} \mathrm{Be}$ in the original sample. Note that the chemical yields of the sample processing technique does not factor in this calculation since we are working with isotopic ratios.
Standard errors (incorporating all sources of experimental and measurement error) for the 117 ice samples ranged from 2.2 to $5.5 \%$ with a median of $2.8 \%$.

\subsection{Dating}

Contiguous high-resolution $(2.5$ to $5.0 \mathrm{~cm}) \delta^{18} \mathrm{O}$ and trace chemistry measurements were carried out on the DSS0506core and on PICO cores extracted alongside the DSS0809and DSS0910-cores. Conversion of the ice core depth scales to timescales was carried out with reference to the clear annual cycles in $\delta^{18} \mathrm{O}$ and trace chemistry observed in these records (van Ommen and Morgan, 1997; Curran et al., 1998). The boundaries of "years" were defined by the mid-summer $\delta^{18} \mathrm{O}$ isotope maximum, which has a mean timing of $10 \mathrm{Jan}-$ uary at DSS (van Ommen and Morgan, 1997). The timescale was developed by interpolating between year boundaries, which assumes even snow accumulation over the course of each year. This assumption is valid for DSS when averaged over many years (van Ommen and Morgan, 1997). However, in any given year, precipitation biases occur and contribute to uncertainty in the timescales. Overall, uncertainty in the dating of individual samples is estimated to be \pm (1 to 2 ) months. This estimate of uncertainty is supported by analysis of the DSS0102-pit chronology. The pit was originally dated using automatic weather station (AWS) records of snow accumulation/ablation events, thus, providing a very accurate timescale (Pedro et al., 2006); re-dating the pit by applying the same technique that was used for the ice core records (i.e., interpolating between year boundaries) results in a timescale that is consistent with the AWS-timescale within the bounds of our estimated dating uncertainty.

\section{Results and discussion}

${ }^{10} \mathrm{Be}$ concentrations in the three ice core records ranged between $(2.13$ and 14.08$) \times 10^{3}$ atoms $\mathrm{g}^{-1}$, with $($ mean $\pm 1 \sigma)$ for all samples $(5.92 \pm 2.05) \times 10^{3}$ atoms $\mathrm{g}^{-1}$.

The records are shown in Fig. 3a) and the $\delta^{18} \mathrm{O}$ ratios measured on the bulk meltwater of each ${ }^{10} \mathrm{Be}$ sample are shown in Fig. 3b). Also shown in these figures are the ${ }^{10} \mathrm{Be}$ concentrations and $\delta^{18} \mathrm{O}$ ratios from the previously reported and contemporaneous DSS snow pit records: the DSS0102-pit and the DSS0506-pit. Note that all of these records are now calibrated to the Nishiizumi et al. (2007) NIST SRM ${ }^{10} \mathrm{Be}:{ }^{9} \mathrm{Be}$ ratio (our previous publications of the DSS0102pit and DSS0506-pit data were calibrated to an earlier NIST value (Pedro et al., 2006, 2009)). Since all samples are referenced to this same standard they can be directly compared.

The results and discussion are arranged as follows: Sect. 3.1 considers the issue of reporting concentrations versus flux; Sect. 3.2 analyses the level of reproducibility between all DSS ${ }^{10} \mathrm{Be}$ records; Sect. 3.3 constructs a $10-\mathrm{yr}$ monthly-resolved composite record of ${ }^{10} \mathrm{Be}$ concentrations; 


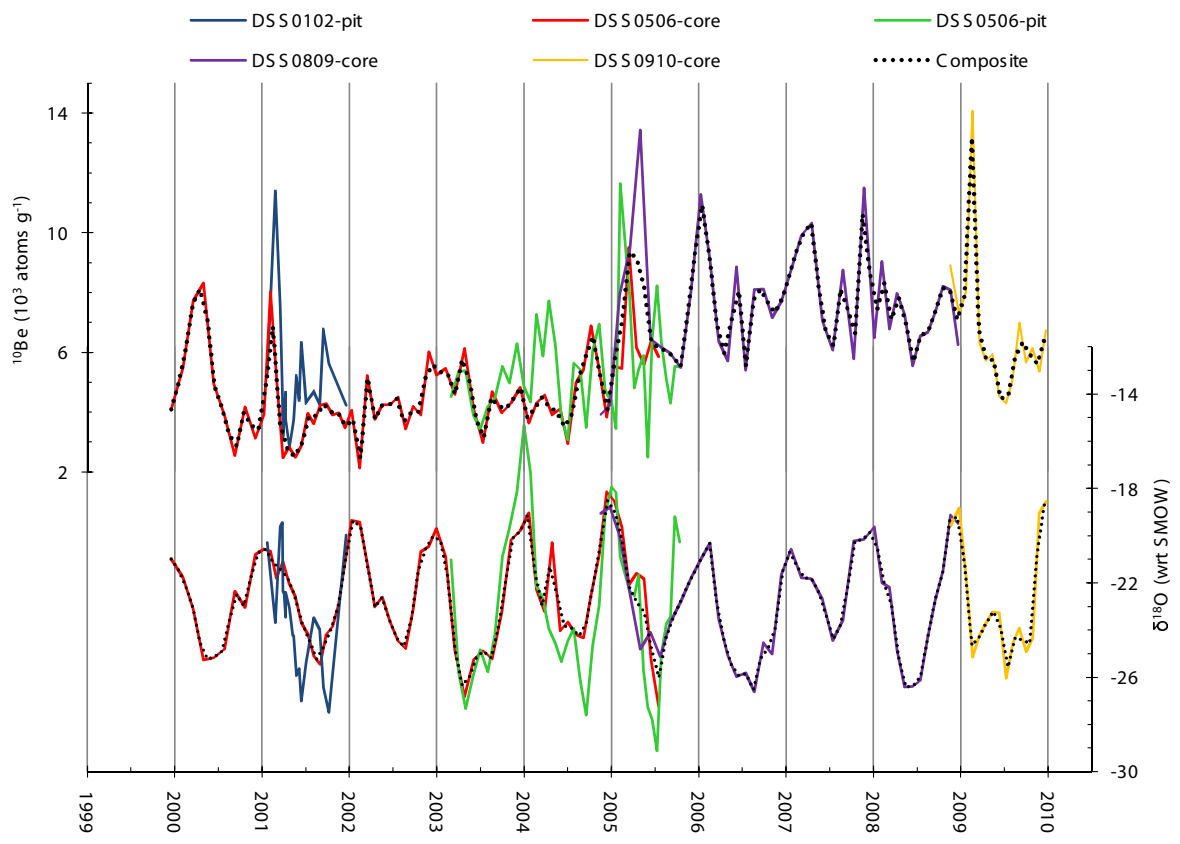

Fig. 3. (a) ${ }^{10} \mathrm{Be}$ concentrations and (b) $\delta^{18} \mathrm{O}$ ratios in three new high-resolution ice core records from DSS, Law Dome (DSS0506-core, DSS0809-core and DSS0910-core), and also in two previously published (Pedro et al., 2006, 2009) snow pits (DSS0102-pit and DSS0506pit). Composite records constructed (see Sect. 3.3) from the ice core series are overlain, providing a 10-yr (1999 to 2009) monthly-resolved record of ${ }^{10} \mathrm{Be}$ concentrations and $\delta^{18} \mathrm{O}$ ratios at DSS. Timescale uncertainty is estimated at $\pm(1$ to 2$)$ months, standard ${ }^{10} \mathrm{Be}$ measurement errors are generally $<3 \%$.

Sect. 3.4 quantifies the variability in ${ }^{10} \mathrm{Be}$ concentrations that may be explained by variations in the GCR and places new constraints on the atmospheric residence time of ${ }^{10} \mathrm{Be}$; and finally, Sect. 3.6 examines meteorological influences on ${ }^{10} \mathrm{Be}$ concentrations.

\subsection{Concentration and flux}

Our analysis is focused on ${ }^{10} \mathrm{Be}$ concentrations in ice rather than on ${ }^{10} \mathrm{Be}$ fluxes, since concentration is the parameter directly measured in the ice. Discussing ${ }^{10} \mathrm{Be}$ variability in terms of flux would require an accurate estimate of accumulation variability. While data on an annual accumulation rate is available at DSS (van Ommen and Morgan, 2010), data on a monthly accumulation variability is highly uncertain and this uncertainty would transfer directly into any inferred flux values. Furthermore, ${ }^{10} \mathrm{Be}$ deposition to Law Dome is dominated by precipitation-related processes, i.e., is wet deposited (Smith et al., 2000; Pedro et al., 2006). At wet deposition sites, changes in accumulation rate are not expected to have a strong influence on concentrations. This is demonstrated at Law Dome by the observation that the concentration of ${ }^{10} \mathrm{Be}$ at three ice core sites across the Dome is independent of the eightfold difference in precipitation rate (Smith et al., 2000).

\subsection{Reproducibility}

Five DSS ${ }^{10} \mathrm{Be}$ records are shown in Fig. 3. The most obvious difference between the records is the greater detail captured by the DSS0102-pit and DSS0506-pit when compared to DSS0506-core. This greater detail is consistent with the snow pit records being sampled at finer depth (and, therefore, time) resolution compared to the ice cores; comparable differences in detail are observed between the corresponding $\delta^{18} \mathrm{O}$ records, supporting this interpretation. There are also some discrepancies in the timing and amplitude of concentration signals between the records. The clearest example of this is the concentration maximum in 2005 that is recorded by the DSS0506-pit, DSS0506-core and DSS0809-core. Between these three records, the timing of the ${ }^{10} \mathrm{Be}$ maxima varies by \pm ( 1 to 2 ) months and its concentration varies between $(9.51$ and 13.43$) \times 10^{3}$ atoms $\mathrm{g}^{-1}$ (i.e., by up to $41 \%$ ). The variations in timing fall within the timescale uncertainty of the records (Sect. 2.5), however, the variations in concentration clearly exceed measurement errors (typically $<3 \%$ ). Such variations in concentration may, therefore, represent real differences caused by environmental factors.

An apparent offset is noticeable between ${ }^{10} \mathrm{Be}$ concentrations in the DSS0102-pit and the DSS0506-core where the records overlap. While both of these records show the same pattern, the mean concentration $( \pm 1 \sigma)$ in the pit, $(5.00 \pm 1.91) \times 10^{3}$ atoms $\mathrm{g}^{-1}$, is $27 \%$ higher than the same 


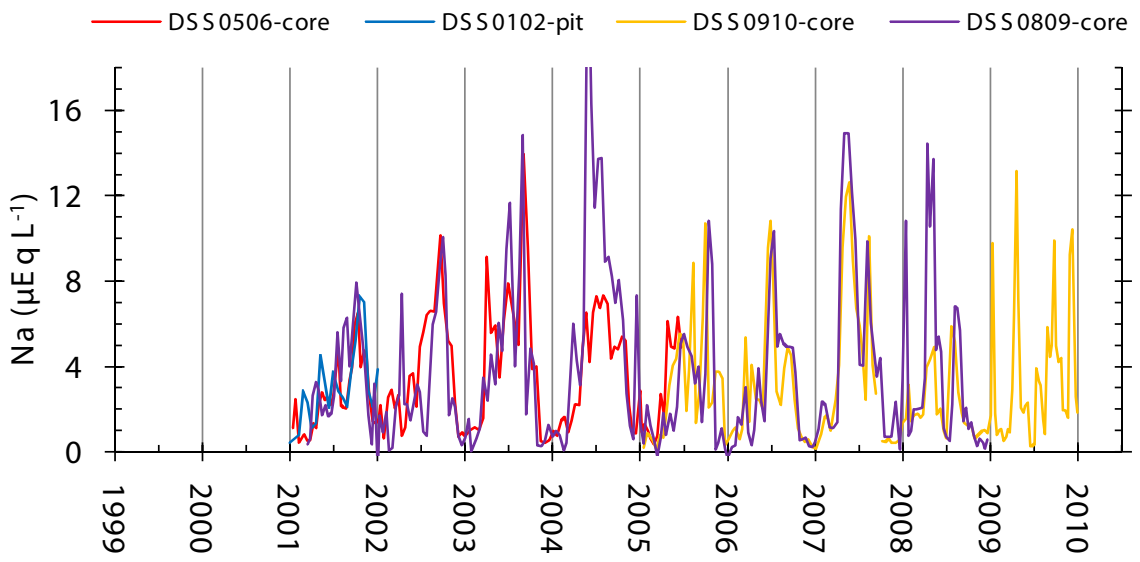

Fig. 4. Intercomparison of $\mathrm{Na}^{+}$concentrations from the same ice core and snow pit records used in the analysis of ${ }^{10} \mathrm{Be}$ reproducibility. Standard measurement error in $\mathrm{Na}^{+}$concentrations are $\sim 15 \%$. Note that trace chemistry was not measured on the DSS0506-pit.

period in the core, $(3.95 \pm 1.4) \times 10^{3}$ atoms $^{-1}$. In selecting a statistical test to determine if this offset is significant, information is first required about the distribution of the ${ }^{10} \mathrm{Be}$ data. Applying a Kolmogorov-Smirnov test (K-S test) for normality rejects the null hypothesis (at $p<0.01$ ) that the ${ }^{10} \mathrm{Be}$ data from these records is normally distributed. Applying the K-S test to the log-transformed ${ }^{10} \mathrm{Be}$ data also rejects the null hypothesis (at $p<0.01$ ) that the data is lognormally distributed (the non-normality of the data results from the sharp concentration maxima that introduce positive skew to the ${ }^{10} \mathrm{Be}$ distribution). Further $\mathrm{K}-\mathrm{S}$ testing revealed that none of the five ${ }^{10} \mathrm{Be}$ series discussed in the text can be described as normally or log-normally distributed (at $p<0.01$ ). Non-parametric tests are, therefore, preferred for treating the ${ }^{10} \mathrm{Be}$ data. We use the Wilcoxon rank-sum test, which tests the null hypothesis that two series are independent samples from identical continuous distributions with equal medians, against the alternative that they do not have equal medians. This test determines that the concentration difference between the DSS0506-core and DSS0102-pit is significant $(p=0.01)$.

According to the Wilcoxon test criteria, no other overlapping sections of core are significantly different at $p<$ 0.05, although in two cases (DSS0506-core and DSS0506pit, DSS0506-pit and DSS0809-PICO), the differences do come close to this level. Differences between the average concentrations, where the records overlap, are in all cases $<1.4 \times 10^{3}$ atoms $\mathrm{g}^{-1}$ or expressed differently, differences range between 10.8 and $24.0 \%$. Full results of statistical tests are provided in Table 2. Our identification of significant and marginally significant differences between records raises the question: do the differences between ${ }^{10} \mathrm{Be}$ records exceed the level of differences previously observed between other trace chemicals at Law Dome?

To answer this question we compared records of other trace chemicals from the corresponding cores. By way of example, the $\mathrm{Na}^{+}$records from the corresponding cores are shown in Fig. 4, and in Table 3 the same analysis applied to the ${ }^{10} \mathrm{Be}$ data is applied to these records. As with ${ }^{10} \mathrm{Be}$, the $\mathrm{Na}^{+}$record shows broadly the same patterns, but some differences in the amplitude of signals between years. According to the Wilcoxon rank-sum test and its criteria, none of the overlapping sections of Na record may be classified as significantly different at $p<0.05$. Nevertheless, large differences in the amplitude of signals are observed in some years, notably in 2004 and 2008. If these years are viewed in isolation then the differences between records would be classified as significant. Overall, with the possible exception of the ${ }^{10} \mathrm{Be}$ concentration offset between DSS0102-pit and DSS0506-core the level of differences between the ${ }^{10} \mathrm{Be}$ records does not appear anomalous with respect to other trace chemical records.

Previous intercomparisons of trace chemicals from Law Dome provide insight into processes responsible for variability between records. Studies of Law Dome snow pits and firn cores have reported generally good spatial reproducibility between trace chemical and $\delta^{18} \mathrm{O}$ records sampled up to $7.7 \mathrm{~km}$ apart (McMorrow et al., 2001, 2002). Differences observed between these records, particularly on a sub-seasonal scale, are attributed to small local variations in snow accumulation, snow surface topography, surface disturbance, ablation and densification between sample sites. By influencing the relative thickness of snow layers corresponding to common meteorological events and, therefore, also the assumptions made during dating (of evenly distributed snow accumulation during the coarse of each year) these processes can alter the timing and amplitude of concentration signals (McMorrow et al., 2001, 2002). Hence, a certain level of variability between all trace chemical records must be regarded as unavoidable. This offers a suitable explanation for the differences between the ${ }^{10} \mathrm{Be}$ records, again with the possible exception of the apparent systematic concentration offset between DSS0102-pit and DSS0506-core. 
Table 2. Inter-comparison of contemporaneous sections of ${ }^{10} \mathrm{Be}$ records from DSS, Law Dome. A Wilcoxon rank-sum hypothesis test (see text) is used to test for significant difference between the pairs of records ( $h=0$ implies no evidence that the records are significantly different at the $95 \%$ CI, i.e., where $p<0.05)$.

\begin{tabular}{lcccc}
\hline Records & & $\begin{array}{c}\text { Period of overlap } \\
\text { (years })\end{array}$ & $\begin{array}{c}\bar{x}( \pm 1 \sigma), \bar{y}( \pm 1 \sigma) \\
\left(\times 10^{3} \text { atoms } \mathrm{g}^{-1}\right)\end{array}$ & $\begin{array}{c}\text { Wilcoxon R-S test } \\
h, p\end{array}$ \\
\hline DSS0506-core \& DSS0102-pit & 14,20 & 0.91 & $3.95( \pm 1.40), 5.00( \pm 1.91)$ & $1,0.01$ \\
DSS0506-core \& DSS0506-pit & 26,35 & 2.35 & $5.00( \pm 1.37), 5.54( \pm 1.90)$ & $0,0.37$ \\
DSS0506-core \& DSS0809-core & 9,7 & 0.68 & $5.97( \pm 1.42), 7.37( \pm 3.06)$ & $0,0.06$ \\
DSS0809-core \& DSS0506-pit & 9,18 & 0.92 & $7.01( \pm 2.95), 6.05( \pm 2.23)$ & $0,0.08$ \\
\hline
\end{tabular}

Since there were differences in the laboratory procedure used to extract the ${ }^{10} \mathrm{Be}$ from the DSS0102-pit and DSS0506core, the possibility cannot be excluded that the offset was due to procedural rather than site-to-site differences. Meltwater from DSS0102-pit samples was acidified with $1 \mathrm{ml}$ per kg ice of concentrated $\mathrm{HNO}_{3}$ prior to filtration (Pedro et al., 2006), whereas the DSS0506-core samples were not acidified. Acidification prior to filtration has two main effects: firstly, the undesirable effect of potentially releasing ${ }^{10} \mathrm{Be}$ atoms from any dust and/or micro meteorites present in the samples (i.e., terrestrial ${ }^{10} \mathrm{Be}$ that is not part of the atmospheric signal we are interested in) (Smith et al., 2000); and secondly, potentially reducing the loss of ${ }^{10} \mathrm{Be}$ atoms by adsorption to filters, tubing and sample bottle walls (Finkel and Nishiizumi, 1997; Yiou et al., 1997). Both of these procedural differences would act in the direction of increasing measured concentrations in the DSS0102-pit samples with respect to DSS0506-core, as observed. The first explanation is inadequate to explain the results, since the available fraction of ${ }^{10} \mathrm{Be}$ associated with dust and micrometeorites in Antarctic ice from the Holocene is very low $(<2 \%$, Lal, 2007; Baumgartner et al., 1997). The second explanation also appears unlikely. Both sample sets were melted in the presence of ${ }^{9} \mathrm{Be}$ carrier, which floods samples with $\sim 10^{13}$ times more ${ }^{9} \mathrm{Be}$ atoms than ${ }^{10} \mathrm{Be}$ atoms. We assume that any loss of ${ }^{10} \mathrm{Be}$ by adsorption to experimental equipment is balanced by loss of ${ }^{9} \mathrm{Be}$ carrier, such that ${ }^{10} \mathrm{Be}:{ }^{9} \mathrm{Be}$ ratios are unaffected. Importantly, this assumption may not hold if the carrier ${ }^{9} \mathrm{Be}$ and ice core ${ }^{10} \mathrm{Be}$ are in different chemical forms and there has not been sufficient time for reaction kinetics to equilibrate ${ }^{9} \mathrm{Be}$ and ${ }^{10} \mathrm{Be}$ atoms between these different forms. There is some evidence that the assumption of equilibrium does break down for Greenland ice samples from the last glacial period with high dust particle concentrations (Finkel and Nishiizumi, 1997; Yiou et al., 1997). This probably relates to non-equilibrium exchange (adsorption and desorption) of ${ }^{10} \mathrm{Be}$ and ${ }^{9} \mathrm{Be}$ between terrestrial dust and meltwater in ways that are not fully understood (Baumgartner et al., 1997). Importantly, Holocene ice samples, with much lower particle concentrations, were negligibly affected by this problem (Finkel and Nishiizumi, 1997; Yiou et al., 1997). The particle concentrations in modern DSS ice are actually among the lowest of all the polar ice core sites (Jun et al., 1998). In addition, recall from Sect. 2.3, that the carrier itself is an acidic solution that typically lowers the sample meltwater $\mathrm{pH}$ to $\sim 4.2$. The aqueous chemistry of Be dictates that at $\mathrm{pH}$ more acidic than 5.7 the dominant species of $\mathrm{Be}$ is the strongly hydrated $\mathrm{Be}^{2+}$, which tends to remain in solution (Everest, 1973). In the absence of dust, we expect the ice core ${ }^{10} \mathrm{Be}$ and carrier ${ }^{9} \mathrm{Be}$ to be in equilibrium in this $\mathrm{Be}^{2+}$ form. Since we cannot completely rule out some selective loss of ${ }^{10} \mathrm{Be}$, we consider it unlikely to have played any major role in the offset between the two DSS records.

An alternative explanation is that the thermal drilling process used to retrieve DSS0506-core may itself have caused some loss of ${ }^{10} \mathrm{Be}$ ions by eluting away some of the soluble ions in the firn with the meltwater produced during drilling. To investigate whether this may have happened, we again consider other trace chemical records. In Fig. $4, \mathrm{Na}^{+}$records from the corresponding pits/cores are plotted. Large intraannual variations are observed in $\mathrm{Na}^{+}$concentrations reflecting seasonal variability in the delivery of this sea-salt species to the ice core site (Curran et al., 1998). In most years, the agreement between the individual $\mathrm{Na}^{+}$records is excellent. Visually, no clear offset is observed between the DSS0102pit and the thermally drilled DSS0506-core, nor between the DSS0809-core and DSS0506-pit, with their longer period of overlap. Applying statistical tests, no significant offset is found between these overlapping records (see Table 3). However, in some years discrepancies are observed, for example 2004 and 2008. These discrepancies are indicative of the level of variability inherent between contemporaneous trace chemical records from these sites. In this context, the differences between ${ }^{10} \mathrm{Be}$ records and, in particular, between the thermally drilled record and physically/mechanically sampled records do not appear anomalous.

To our knowledge there has been only one other investigation of the reproducibility of ice core ${ }^{10} \mathrm{Be}$ records (Moraal et al., 2005). This study found up to a fourfold difference in ${ }^{10} \mathrm{Be}$ concentrations between two records sampled $300 \mathrm{~m}$ apart. However, this study was not carried out at a proven ice core site, instead, it was an opportunistic effort to retrieve ${ }^{10} \mathrm{Be}$ samples from cargo loading ramps that are cut annually into the Queen Maud Land (QML) ice shelf for the 
Table 3. Inter-comparison of contemporaneous sections of $\mathrm{Na}^{+}$records from the same ice cores and snow pits used in the analysis of ${ }^{10} \mathrm{Be}$ reproducibility. As in Table 2, a Wilcoxon rank-sum hypothesis test is used to test the null hypothesis that the two series are independent samples from identical continuous distributions with equal medians $(h=1$ implies that the null hypothesis should be rejected as $p<0.05)$. Note that trace chemistry was not measured on the DSS0506-pit.

\begin{tabular}{lcccc}
\hline $\begin{array}{l}\mathrm{Na}^{+} \text {Records } \\
x, y\end{array}$ & $n_{\mathrm{x}}, n_{\mathrm{y}}$ & $\begin{array}{c}\text { Period of overlap } \\
\text { (years })\end{array}$ & $\begin{array}{c}\bar{x}( \pm 1 \sigma), \bar{y}( \pm 1 \sigma) \\
\left(\times 10^{3} \text { atoms } \mathrm{g}^{-1}\right)\end{array}$ & $\begin{array}{c}\text { Wilcoxon R-S test } \\
h, p\end{array}$ \\
\hline DSS0506-core \& DSS0102-pit & 28,20 & 0.91 & $2.57( \pm 1.64), 3.11( \pm 1.84)$ & $0,0.30$ \\
DSS0506-core \& DSS0708-core & 111,101 & 4.42 & $3.41( \pm 2.57), 3.81( \pm 2.76)$ & $0,0.37$ \\
DSS0506-core \& DSS0809-core & 106,112 & 4.26 & $3.52( \pm 2.57), 3.88( \pm 4.04)$ & $0,0.60$ \\
DSS0809-core \& DSS0910-core & 107,101 & 3.93 & $3.42( \pm 3.68), 3.00( \pm 2.88)$ & $0,0.99$ \\
\hline
\end{tabular}

purpose of resupply of the South African research station. Moraal et al. (2005) were unable to determine the reason for the major discrepancy between these records. However, they suggested that local-scale and/or post-depositional influences may have been involved.

A number of factors may have contributed to the poor reproducibility in the QML study. The study site was not ideal for a number of reasons: (i) one of the loading ramp faces used for sampling had been exposed to the atmosphere for $1 \mathrm{yr}$ prior to sampling, potentially contaminating the record with chemicals (including from sea spray) that were not present at the time of snow deposition and leaving the record vulnerable to solar ablation, aeolian ablation and melt, (ii) snow accumulation at the sampling site itself is very low with most accumulation arriving as snow drift from other regions, making the record difficult to interpret and sensitive to shifts in prevailing wind patterns between years, and (iii) surface melt-layers occur annually at the site, leading to post-depositional changes to the chemistry record. All of these factors act against the preservation of reliable ice core records. The long exposure of one of the sampling faces to the atmosphere prior to sampling, may have been the critical factor; it was this exposed record that had much lower concentrations than the record sampled from the freshly cut cargo ramp. Field and laboratory studies suggest that at sites where annual melt layers are common, melt-water percolation can remove 50 to $80 \%$ of the soluble ion fraction from the snow-pack (Johannessen and Henriksen, 1978; Eichler et al., 2001; Hou and Qin, 2002). Excessive melt of the exposed sampling face, therefore, offers a plausible explanation for the concentrations difference between the two QML records. When compared to the much higher level of reproducibility observed at the more controlled DSS ice core site, the QML result appears more likely to be related to problems with the sampling site and methodology rather than any inherent problem in the reproducibility of ${ }^{10} \mathrm{Be}$ records.

Overall, our results support the reproducibility of ${ }^{10} \mathrm{Be}$ records obtained from proven high resolution ice core sites. This result is encouraging from the perspective of using ${ }^{10} \mathrm{Be}$ as a solar activity proxy. However, we advise some caution in interpreting absolute concentration differences between dif- ferent records/sites that have not been collected and prepared identically.

\section{3 ${ }^{10}$ Be composite record}

A monthly resolution $10-y r$ composite record is constructed from the DSS ${ }^{10} \mathrm{Be}$ data in order to obtain the longest possible record for intercomparison with other geophysical data series. DSS0506-core, DSS0809-core and DSS0910-core are used for the composite (all of which were sampled at similar resolution and prepared for measurement identically). All three records were resampled to even (monthly) sample spacing by linear interpolation. As monthly spacing is close to the mean resolution of the original data, the effect of this resampling is benign. For periods where there is an overlap between records, the average of the records was used. We neglect the comparatively small influence of measurement errors (typically $<3 \%$ ).

The composite record is shown in Fig. 3a as the dashed line overlain on the original time series. A composite $\delta^{18} \mathrm{O}$ record was also constructed using the same technique and is shown as the dashed line in Fig. 3b). In constructing the composite, more complicated methods of data splicing and interpolation were also trialled, however, the resulting differences were negligible, therefore, the simple technique outlined above was preferred.

\subsection{Production rate signal}

Neutron monitor data is the best measured parameter against which to test modern ice core ${ }^{10} \mathrm{Be}$ data for a production rate signal (e.g. Steig et al., 1996; Berggren et al., 2009). Here, we use the neutron counting rate on the McMurdo Neutron Monitor, Antarctica (from the Bartol Research Institute).

Figure 5a shows ${ }^{10} \mathrm{Be}$ concentrations alongside the monthly average McMurdo neutron counting rate. On interannual timescales there is an obvious relation between the neutron counting rate and the ${ }^{10} \mathrm{Be}$ concentration. The strength of this relationship is explored by calculating Pearson's correlation coefficient $\left(r_{\mathrm{xy}}\right)$ as the lag between ${ }^{10} \mathrm{Be}$ and the neutron counting rate is varied (Fig. 5c). We employ a 
non-parametric stationary bootstrap method in the calculation $\left(r_{\mathrm{xy}}\right)$ and associated $95 \%$ (bias-corrected and accelerated) confidence intervals (CI). An important advantage of this method over conventional techniques is that it yields reliable confidence intervals for $\left(r_{\mathrm{xy}}\right)$ when applied to serially dependent and non-normally distributed data series (Mudelsee, 2003). At zero lag, a highly significant correlation is observed, $r_{\mathrm{xy}}=0.64$ (with $95 \% \mathrm{CI}$ of 0.53 to 0.71 ), as shown in Fig. 5b). This indicates a production signal in the composite record coherent with Schwabe cycle modulation of the GCR. Our results suggest that the production signal accounts for $\sim 40 \%$ of the variance in ${ }^{10} \mathrm{Be}$ concentrations over the 10 -yr series. Concentrations during the solar minimum years $(2008,2009)$ are a factor of 1.64 times those during the solar maximum years $(2001,2002,2003)$. According to the Wilcoxon rank-sum test, this difference is significant at $p<1 \times 10^{-8}$.

The concentration difference between solar maximum and solar minimum exceed the theoretical variation in the global atmospheric production rate over the same interval, which was a factor of 1.34 (calculated using the cosmic ray modulation strength $(\Phi)$ values of Usoskin et al., 2005 and the crosssections and alpha correction of Masarik and Beer, 2009). Interestingly, the concentration difference is comparable to the theoretical variation in the polar (i.e., 60 to $90^{\circ} \mathrm{S}$ ) atmospheric production rate, which was a factor 1.59. The question of whether the ${ }^{10} \mathrm{Be}$ deposited to the polar regions should reflect changes in the global production rate, polar production rate, or some mixture of both is still not settled (see, Mazaud et al., 1994; Steig et al., 1996; Bard et al., 2000; McCracken, 2004; Field et al., 2006; Heikkilä et al., 2008a). However, given that the DSS record samples only one Schwabe cycle, it would be premature to draw too much from our result. It may be that meteorological influences that are unrelated to production variations have contributed to enhance the concentration differences above what may be attributed to global production rate changes alone. A study currently underway at DSS looking at ${ }^{10} \mathrm{Be}$ concentrations over multiple Schwabe cycles will provide greater insight into this issue.

Theoretical studies suggest that globally $\sim 50$ to $75 \%$ of ${ }^{10} \mathrm{Be}$ production occurs in the stratosphere (Masarik and Beer, 1999; Heikkilä et al., 2008a). Atmospheric residence times in the stratosphere are of order 1 to $2 \mathrm{yr}$ whilst residence times in the troposphere are substantially shorter, of order several weeks (Raisbeck et al., 1981; Jordan et al., 2003; Heikkilä et al., 2009). The behaviour of $r_{\mathrm{xy}}$ as lag is increased (Fig. 5c) provides empirical information on the atmospheric residence time of ${ }^{10} \mathrm{Be}$. As the lag is varied beyond 10 months, $r_{\mathrm{xy}}$ begins to decline (Fig. 5c). At lag 18 months the correlation is already significantly lower (at $95 \% \mathrm{CI}$ ) than for lags less than 10 months. When the lag is varied beyond 24 months, the correlation is not significantly different from zero. This lag-correlation analysis suggests that most ${ }^{10} \mathrm{Be}$ arriving to DSS has been produced in the at-
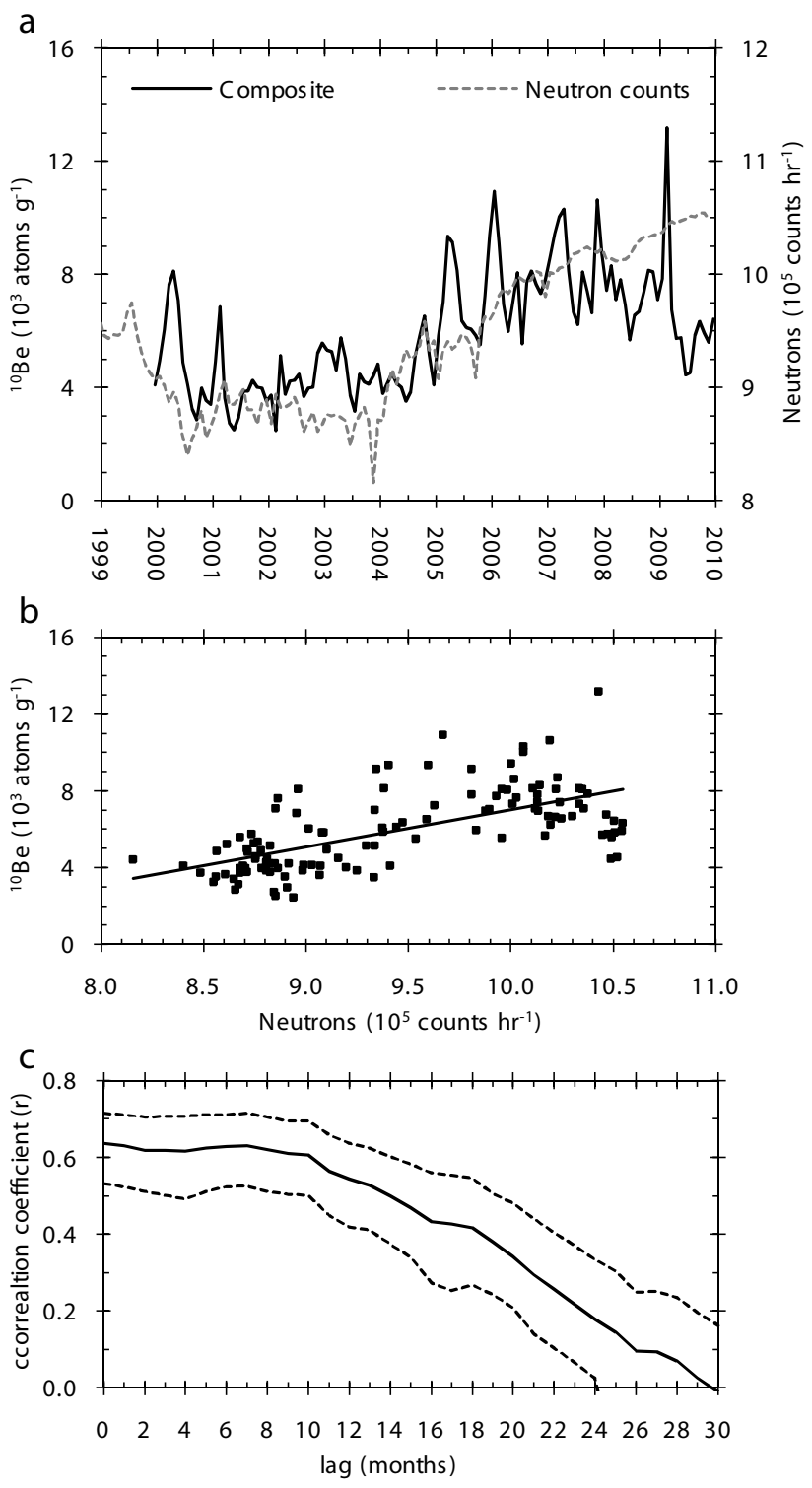

Fig. 5. The relationship between ${ }^{10} \mathrm{Be}$ concentrations in the DSS composite record and the neutron counting rate on the McMurdo neutron monitor, Antarctica. (a), Concentrations of ${ }^{10} \mathrm{Be}$ (black line) compared to the neutron counting rate (dashed grey line). (b), Concentrations of ${ }^{10} \mathrm{Be}$ plotted against the neutron counting rate (at zero lag) with a linear regression line fitted to the data. (c), The correlation coefficient between ${ }^{10} \mathrm{Be}$ concentration and the neutron counting rate as the lag of ${ }^{10} \mathrm{Be}$ behind neutron counts is varied (black line) and the $95 \% \mathrm{CI}$ around the correlation coefficient (dashed blacked lines). Measurement errors in ${ }^{10} \mathrm{Be}$ concentrations are typically $<3 \%$, and timescale errors are \pm (1 to 2 ) months, errors in the neutron counting rate are negligible.

mosphere within the previous 0 to 10 months. Given that stratospheric and tropospheric lifetimes bracket this range, this result argues for appreciable contributions from both of these sources to total ${ }^{10} \mathrm{Be}$ fallout at the site. Resolving the precise contribution of each reservoir to total depositions 
is not yet possible empirically, however, ${ }^{7} \mathrm{Be}$ measurements now underway on snow pit samples from DSS are expected to help in this respect.

While on interannual timescales the atmospheric production emerges as a principal control on concentrations in ice, factors other than production also have considerable influence. Maximum levels for the 10-yr composite are reached in the summer to autumn of 2009, however, average annual concentrations actually decline over the period 2008 to 2009. This is in contrast to neutron counting rates at high latitudes, which in 2009 actually reached their highest levels since the installation of monitors in the 1960s (Moraal et al., 2009); coinciding with the deepest solar minimum (according to various parameters) since the 1920s (Lockwood et al., 2009; Lockwood, 2010). These indicators imply an atmospheric ${ }^{10} \mathrm{Be}$ production rate at record high levels with respect to the same historical interval. The divergence between ${ }^{10} \mathrm{Be}$ and neutron counting rates must, therefore, be explained by non-production factors. Since the procedure for extraction of ${ }^{10} \mathrm{Be}$ from melt-water was identical for all of the records used in the composite, chemical processing factors do not explain the divergence. This leaves meteorological influences or local/in-situ effects (e.g., local variations in snow accumulation, snow surface topography, ablation and other forms of surface disturbance) as the most probable explanation.

\subsection{Solar cosmic ray events}

A previous paper (Pedro et al., 2009) reporting results from the DSS0506-pit investigated whether the concentration peak in summer 2005 may have been a response to the 20 January 2005 solar cosmic ray event. This event was calculated to increase monthly cumulative ${ }^{10} \mathrm{Be}$ production in the polar atmosphere by $\sim 120 \%$ above the GCR background (Webber et al., 2007). The new ${ }^{10} \mathrm{Be}$ records reported here also replicate the summer 2005 peak. However, with the benefit of these longer records it is seen that the 2005 peak is not anomalous, for example, the concentration is exceeded by the maximum in summer 2009. Careful analysis of ${ }^{10} \mathrm{Be}$ concentrations following a number of historically recorded solar cosmic ray events will now be required in order to judge whether the events can trigger short-term peaks in the ice core data.

\subsection{Meteorological signals}

\subsubsection{Influence of stratospheric air}

On monthly timescales, there are large variations in concentration that cannot be explained by production variations. Short-lived (1 to 2 months) events of particularly high concentration (more than $2 \sigma$ above the mean) occur in some years, typically in summer to autumn, e.g., 2001 and 2005 to 2009. Comparable events are absent or damped during the solar maximum (neutron counting minimum) years of 2002 to 2004 .
We are not aware of any monthly-resolved ${ }^{10} \mathrm{Be}$ records from other Antarctic sites with which to compare the DSS composite. However, there are at least two such records available from Greenland. The first is from a snow pit spanning 1978 to 1983 from the Dye 3 site in south Greenland (Beer et al., 1991). The second is from a snow pit spanning 1986 to 1990 from the GRIP site in central Greenland (Heikkilä et al., 2008b). Similarly to DSS, both Greenland sites experience short-lived concentration maxima. An important difference between the Antarctic and Greenland records is that the concentration maximum typically occurs during the (austral) summer to autumn in Antarctica, whereas in Greenland there is suggestion of a bimodal pattern with a primary maximum in the (boreal) summer to autumn and a secondary maximum in the (boreal) spring.

The sharp concentration peaks in the ${ }^{10} \mathrm{Be}$ data resemble features observed in a recently compiled series spanning 1975 to 2006 of ${ }^{10} \mathrm{Be}$ and ${ }^{7} \mathrm{Be}$ concentrations in ground-level air samples from two sites in Sweden (Aldahan et al., 2008). In this study, sporadic events of $>2$ to 3 times average concentrations were observed in some years, typically in spring to summer. The authors concluded that the sporadic peaks were likely caused by intrusions of ${ }^{10} \mathrm{Be}$ rich air from the stratosphere, they suggested further that such a mechanism may explain relative peaks in ice core ${ }^{10} \mathrm{Be}$ records. Our results appear to support this view. According to the most detailed model study yet of atmospheric transport into the polar troposphere (Stohl and Sodemann, 2010), and in agreement with the timing of the concentration peaks observed here, summer to autumn is the period during which there is the highest probability of encountering air of recent stratospheric origin in the Antarctic troposphere. Maximum influence of stratospheric air during the summer to autumn is also supported by signals observed in numerous other stratospheric aerosol markers at Antarctic air sampling stations (Raisbeck et al., 1981; Sanak et al., 1985; Feeley et al., 1989; Savoie et al., 1992; Wagenbach, 1996).

\subsubsection{Relationship between ${ }^{10} \mathrm{Be}$ and $\delta^{18} \mathrm{O}$}

Results from an earlier analysis of the DSS0102-pit suggested an important meteorological influences on ${ }^{10} \mathrm{Be}$ forced by variability in local meteorology and air mass moisture history (Pedro et al., 2006). This influence was detected in the form of a significant negative correlation $\left(r_{\mathrm{xy}}=\right.$ $0.57, p<0.01)$ between first-differences in $\delta^{18} \mathrm{O}$ and ${ }^{10} \mathrm{Be}$ measurements. The relationship can now be tested over the 10-yr composite.

Following the procedure in (Pedro et al., 2006), firstdifferences in ${ }^{10} \mathrm{Be}$ concentrations are tested against firstdifferences in $\delta^{18} \mathrm{O}$. This yields $r_{\mathrm{xy}}=-0.14$ with a $95 \% \mathrm{CI}$ of -0.38 to 0.02 . This negative relationship is consistent with, although weaker than, that observed in the pervious study. Indeed, the $95 \% \mathrm{CI}$ around $r_{\mathrm{xy}}$ indicates that the significance of the relation is marginal. Notably, there is no 
trend in $\delta^{18} \mathrm{O}$ capable of offering an explanation for the departure of ${ }^{10} \mathrm{Be}$ concentrations from the neutron counting rate curve in 2008 and 2009.

An important difference with respect to our earlier study that may explain this weaker correlation is the sub-monthly (snowfall event scale) resolution of DSS0102-pit compared to the coarser monthly-resolution of the composite. The implication is that ${ }^{10} \mathrm{Be}$ and $\delta^{18} \mathrm{O}$ co-vary at DSS on the snowfall event scale, but that this relation appears to deteriorate with coarser sample resolution. This is also an encouraging result from the perspective of interpreting information about atmospheric production from ice core ${ }^{10} \mathrm{Be}$.

\section{Summary and conclusions}

We have described the methodology used to obtain highresolution and well-dated ice core records of ${ }^{10} \mathrm{Be}$ from the DSS ice core site and presented three new records. Combined, these datasets provide a record of near-monthly variations in the concentration of ${ }^{10} \mathrm{Be}$ over the past decade at the DSS ice core site. In comparing the records with previously reported snow pit records sampled from up to $500 \mathrm{~m}$ away, variations of up to $40 \%$ between records during individual months are observed. This short-term variability is attributed to local-scale differences between sites in accumulation, ablation and density profiles and potentially differences in the experimental procedure that applied to one of the records (DSS0102-pit). When records are averaged across their overlapping intervals (ranging from 0.91 to $2.35 \mathrm{yr}$ ) agreement improves. For the records with the longest period of overlap the absolute difference is $0.54 \times 10^{3}$ atoms $\mathrm{g}^{-1}$, or $10.8 \%$. Overall, the agreement between ${ }^{10} \mathrm{Be}$ records is comparable to that observed between other commonly measured trace chemicals, supporting the reproducibility of ${ }^{10} \mathrm{Be}$ records sampled from the DSS site.

Our results illustrate that ${ }^{10} \mathrm{Be}$ records are more reliable when sampled from proven or carefully selected ice core sites; by contrast, sites where melt layers are common, where windblown snow contributes a large fraction of annual accumulation, where the snow pack has been disturbed or where sampling surfaces have been left open to the atmosphere should probably be avoided if the intent is to obtain a record which can inform on the atmospheric production rate. Also, caution should be taken in comparing absolute concentrations between records that have not been prepared for AMS measurement identically. Further study directed at constraining site-to-site differences between records, or differences attributable to in-situ effects on annual and greater timescales is worthwhile, and ideally would require some decades of identically prepared contemporaneous records.

A composite record spanning the past decade was constructed from the three (identically prepared) DSS ${ }^{10} \mathrm{Be}$ ice cores. Using this record, we find that the neutron counting rate, a measure of the cosmic ray flux, can explain up to $\sim 40 \%$ of the variance in ${ }^{10} \mathrm{Be}$ concentrations at the site. The phase relationship of ${ }^{10} \mathrm{Be}$ and the neutron counting rate is consistent with the bulk of the ${ }^{10} \mathrm{Be}$ arriving to Law Dome having been produced in the atmosphere during the previous 0 to 10 months.

The atmospheric production rate is responsible for the principal trend in concentrations on interannual timescales. However, the relation appears to break down during 2008 to 2009 when neutron counting rates increase to unusually high levels whilst ${ }^{10} \mathrm{Be}$ concentrations actually decrease. In our assessment, this divergence must be caused by some unexplained meteorological influence or local/in-situ processes (e.g., local variations in snow accumulation, snow surface topography, ablation or other forms of surface disturbance).

On monthly timescales there are large variations in concentration that cannot be explained by production variations. It appears that short-term peaks in ${ }^{10} \mathrm{Be}$ concentrations may be associated with input of stratospheric air into the polar troposphere. Similarly, to a previous study at DSS a negative relation is found between ${ }^{10} \mathrm{Be}$ and $\delta^{18} \mathrm{O}$, however the relation is much weaker than that observed previously.

Summing up, our results allay some concerns about poor reproducibility of ${ }^{10} \mathrm{Be}$ records sampled from polar ice core sites. At suitable ice core sites, ${ }^{10} \mathrm{Be}$ records should respond primarily to changes in atmospheric production with additional influence from climate and meteorological variability. At Law Dome the atmospheric production rate is strongly represented in the concentration data. This, along with increasing understanding of climate and meteorological influences on ${ }^{10} \mathrm{Be}$ deposition, marks Law Dome as a valuable site for extraction of longer term records of ${ }^{10} \mathrm{Be}$ for investigation of past variations in solar activity and cosmic ray intensity.

The datasets are available online at the Australian Antarctic Data Centre (http://data.aad.gov.au/) and at the World Data Centre for Paleoclimatology (http://www.ncdc.noaa. gov/paleo/).

Acknowledgements. The authors acknowledge support from the Australian Antarctic Division (Australian Antarctic Science Projects AAS\#2384, AAS\#3064 and AAS\#1172), the Australian Governments Cooperative Research Centres Programme through the Antarctic Ecosystems and Climate Cooperative Research Centre (ACE CRC), the Australian Institute of Nuclear Science and Engineering (AINSE) and the Cosmogenic Climate Archives of the Southern Hemisphere (CcASH) project in the Institute for research at the Australian Nuclear Science and Technology Organisation (ANSTO). J. B. P. is supported by an Australian Post-Graduate Award and an AINSE Post-Graduate Award. We thank the Bartol Research Institute neutron monitor programme, supported by National Science Foundation grant ATM-0527878, for making the McMurdo neutron record available. We thank Andrew Moy for measuring the $\delta^{18} \mathrm{O}$ records. Ulla Heikkilä provided valuable comments on an earlier version of the manuscript. Finally, we are most grateful to William Webber and two anonymous referees for their reviews that led to an improved final manuscript.

Edited by: N. Abram 


\section{References}

Aldahan, A., Possnert, G., Johnsen, S., Clausen, H., Isaksson, E., Karlen, W., and Hansson, M.: Sixty year ${ }^{10}$ Be record from Greenland and Antarctica, in: Proc. Indian. Acad. Sci., Earth Planet. Sci., 107, 139-147, 1998.

Aldahan, A., Hedfors, J., Possnert, G., Kulan, A., Berggren, A.M., and Söderström, C.: Atmospheric impact on beryllium isotopes as solar activity proxy, Geophys. Res. Lett., 35, L21812, doi:10.1029/2008GL035189, 2008.

Bard, E., Raisbeck, G., Yiou, F., and Jouzel, J.: Solar irradiance during the last 1200 years based on cosmogenic nuclides, Tellus Series B Chemical and Physical Meteorology B, 52, 985-992, doi:10.1034/j.1600-0889.2000.d01-7.x, 2000.

Bartol Research Institute: Neutron monitor program, McMurdo monitor data, http://neutronm.bartol.udel.edu/, access: December 2010 .

Baumgartner, S., Beer, J., Wagner, G., Kubik, P., Suter, M., Raisbeck, G. M., and Yiou, F.: ${ }^{10} \mathrm{Be}$ and dust, Nuclear Instruments and Methods in Physics Research Section B: Beam Interactions with Materials and Atoms, 123, 296-301, doi:10.1016/S0168583X(96)00751-3, 1997.

Beer, J.: Long-term indirect indices of solar variability, Space Science Reviews, 94, 53-66, 2000.

Beer, J., Blinov, A., Bonani, G., Hofmann, H. J., and Finkel, R. C.: Use of Be-10 in polar ice to trace the 11-year cycle of solar activity, Nature, 347, 164-166, doi:10.1038/347164a0, 1990.

Beer, J., Finkel, R. C., Bonani, G., Gäggerler, H., Görlach, U., Jacob, P., Klockow, D., Langaway, C. C., A., N., Oeschger, H., Schotterer, U., Schwander, J., Siegenthaler, U., Suter, M., Wagenbach, D., and W., W.: Seasonal variations in the concetration of ${ }^{10} \mathrm{Be}, \mathrm{Cl}^{-}, \mathrm{NO}_{3}^{-}, \mathrm{SO}_{4}^{2-}, \mathrm{H}_{2} \mathrm{O}_{2},{ }^{210} \mathrm{~Pb},{ }^{3} \mathrm{H}$, mineral dust, and $\delta^{18} \mathrm{O}$ in Greenland snow, Atmos. Environ., 25A, 899-904, 1991.

Berggren, A., Beer, J., Possnert, G., Aldahan, A., Kubik, P., Christl, M., Johnsen, S. J., Abreu, J., and Vinther, B. M.: A 600-year annual ${ }^{10} \mathrm{Be}$ record from the NGRIP ice core, Greenland, Geophys. Res. Lett., 36, L11801, doi:10.1029/2009GL038004, 2009.

Burn-Nunes, L. J., Vallelonga, P., Loss, R. D., Burton, G. R., Moy, A., Curran, M., Hong, S., Smith, A. M., Edwards, R., Morgan, V., and Rosman, K. J. R.: Seasonal variability in the input of lead, barium and indium to Law Dome, Antarctica, Geochim. Cosmochim. Ac., 75, 1-20, doi:10.1016/j.gca.2010.09.037, 2011.

Child, D., Elliott, G., Mifsud, C., Smith, A. M., and Fink, D.: Sample processing for earth science studies at ANTARES, Nuclear Instruments and Methods in Physics Research B, 172, 856-860, 2000.

Curran, M. A. J. and Palmer, A. S.: Suppressed ion chromatography methods for the routine determination of ultra low level anions and cations in ice cores, J. Chromatogr. A, 919, 107-113, doi:10.1016/S0021-9673(01)00790-7, 2001.

Curran, M. A. J., van Ommen, T. D., and Morgan, V.: Seasonal characteristics of the major ions in the high-accumulation Dome Summit South ice core, Law Dome, Antarctica, Ann. Glaciol., 27, 385-390, 1998.

Eichler, A., Schwikowski, M., and Gaggeler, H. W.: Meltwaterinduced relocation of chemical species in Alpine firn, Tellus B, 53, 192-203, doi:10.1034/j.1600-0889.2001.d01-15.x, 2001.

Everest, D. A.: Comprehensive Inorganic Chemistry, chap. 9. Beryllium, 531-590, Pergamon, 1973.
Feeley, H. W., Larsen, R. J., and Sanderson, C. G.: Factors that cause seasonal variations in beryllium-7 concentrations in surface air, J. Environ. Radioactiv., 9, 223-249, 1989.

Field, C. V. and Schmidt, G. A.: Model-based constraints on interpreting 20th century trends in ice core ${ }^{10} \mathrm{Be}$, J. Geophys. Res.Atmos., 114, D12110, doi:10.1029/2008JD011217, 2009.

Field, C. V., Schmidt, G. A., Koch, D., and Salyk, C.: Modeling production and climate-related impacts on ${ }^{10} \mathrm{Be}$ concentration in ice cores, J. Geophys. Res.-Atmos., 111, D15107, doi:10.1029/2005JD006410, 2006.

Fink, D., McKelvey, B., Hannan, D., and Newsome, D.: Cold rocks, hot sands: In-situ cosmogenic applications in Australia at ANTARES, Nucl. Instrum. Methods, 172, 838-846, 2000.

Finkel, R. C. and Nishiizumi, K.: Beryllium 10 concentrations in the Greenland Ice Sheet Project 2 ice core from 3-40 ka, J. Geophys. Res., 102, 26699-26706, doi:10.1029/97JC01282, 1997.

Heikkilä, U., Beer, J., and Feichter, J.: Modeling cosmogenic radionuclides ${ }^{10} \mathrm{Be}$ and ${ }^{7} \mathrm{Be}$ during the Maunder Minimum using the ECHAM5-HAM General Circulation Model, Atmos. Chem. Phys., 8, 2797-2809, doi:10.5194/acp-8-2797-2008, 2008a.

Heikkilä, U., Beer, J., Jouzel, J., Feichter, J., and Kubik, P.: ${ }^{10} \mathrm{Be}$ measured in a GRIP snow pit and modeled using the ECHAM5-HAM general circulation model, Geophys. Res. Lett., 35, L05817, doi:10.1029/2007GL033067, 2008b.

Heikkilä, U., Beer, J., and Feichter, J.: Meridional transport and deposition of atmospheric 10Be, Atmos. Chem. Phys., 9, 515527, doi:10.5194/acp-9-515-2009, 2009.

Horiuchi, K., Uchida, T., Sakamoto, Y., Ohta, A., Matsuzaki, H., Shibata, Y., and Motoyama, H.: Ice core record of ${ }^{10} \mathrm{Be}$ over the past millennium from Dome Fuji, Antarctica: A new proxy record of past solar activity and a powerful tool for stratigraphic dating, Quat. Geocrhonology, 3, 253-261, 2008.

Hou, S. and Qin, D.: The effect of postdepositional process on the chemical profiles of snow pits in the percolation zone, Cold Reg. Sci. Tech., 34, 111-116, doi:10.1016/S0165-232X(01)00065-9, 2002.

Johannessen, M. and Henriksen, A.: Chemistry of Snow Meltwater: Changes in Concentration During Melting, Water Resour. Res., 14, 615-619, doi:10.1029/WR014i004p00615, 1978.

Jones, P. D., Briffa, K. R., Osborn, T. J., Lough, J. M., van Ommen, T. D., Vinther, B. M., Luterbacher, J., Wahl, E. R., Zwiers, F. W., Mann, M. E., Schmidt, G. A., Ammann, C. M., Buckley, B. M., Cobb, K. M., Esper, J., Goosse, H., Graham, N., Jansen, E., Kiefer, T., Kull, C., Küttel, M., Mosley-Thompson, E., Overpeck, J. T., Riedwyl, N., Schulz, M., Tudhope, A. W., Villalba, R., Wanner, H., Wolff, E., and Xoplaki, E.: High-resolution palaeoclimatology of the last millennium: a review of current status and future prospects, The Holocene, 19, 3-49, 2009.

Jordan, C. E., Dibb, J. E., and Finkel, R. C.: ${ }^{10} \mathrm{Be} /{ }^{7} \mathrm{Be}$ tracer of atmospheric transport and stratosphere-troposphere exchange, J. Geophys. Res.-Atmos., 108, 4234, doi:10.1029/2002JD002395, 2003.

Jun, L., Jacka, T. H., and Morgan, V.: Crystal-size and microparticle record in the ice core from Dome Summit South, Law Dome, East Antarctica, Ann. Glaciol., 27, 343-348, 1998.

Lal, D.: Recycling of cosmogenic nuclides after their removal from the atmosphere; special case of appreciable transport of ${ }^{10} \mathrm{Be}$ to polar regions by aeolian dust, Earth Planet. Sci. Lett., 264, 177187, doi:10.1016/j.eps1.2007.09.030, 2007. 
Lal, D. and Peters, B.: Cosmic ray produced radioactivity on the Earth, in: Handbuch der Physik, edited by: Flugge, S., 46, 551612, Springer, 1967.

Lean, J. L., Wang, Y.-M., and Sheeley, N. R.: The effect of increasing solar activity on the Sun's total and open magnetic flux during multiple cycles: Implications for solar forcing of climate, Geophys. Res. Lett., 29, 2224, doi:10.1029/2002GL015880, 2002.

Lockwood, M.: Solar change and climate: an update in the light of the current exceptional solar minimum, Proc. R. Soc. A., 466, 303-329, doi:10.1098/rspa.2009.0519, 2010.

Lockwood, M., Rouillard, A. P., and Finch, I. D.: The Rise and Fall of Open Solar Flux During the Current Grand Solar Maximum, The Astrophysical Journal, 700, 937-944, doi:10.1088/0004637X/700/2/937, 2009.

Masarik, J. and Beer, J.: Simulation of particle fluxes and cosmogenic nuclide production in the Earth's atmosphere., J. Geophys. Res., 104, 12099-12111, 1999.

Masarik, J. and Beer, J.: An updated simulation of particle fluxes and cosmogenic nuclide production in the Earth's atmosphere., J. Geophys. Res., 114, D11103, doi:10.1029/2008JD010557, 2009.

Mazaud, A., Laj, C., and Bender, M.: A geomagnetic chronology for antarctic ice accumulation, Geophys. Res. Lett., 21, 337-340, doi:10.1029/93GL02789, 1994.

McCracken, K. G.: Geomagnetic and atmospheric effects upon the cosmogenic ${ }^{10} \mathrm{Be}$ observed in polar ice, J. Geophys. Res.-Space, 109, A04101, doi:10.1029/2003JA010060, 2004.

McCracken, K. G., McDonald, F. B., Beer, J., Raisbeck, G., and Yiou, F.: A phenomenological study of the long-term cosmic ray modulation, 850-1958 AD, J. Geophys. Res.-Space, 109, A12103, doi:10.1029/2004JA010685, 2004.

McMorrow, A. J., Curran, M. A. J.and van Ommen, T. D., Morgan, V. I., J., P. M. A., and Allison, I.: Intercomparison of firn-core and meteorological data, Antarct. Sci., 13, 329-337, 2001.

McMorrow, A. J., Curran, M. A. J., van Ommen, T. D., Morgan, V. I., and Allison, I.: Features of meteorological events preserved in a high-resolution Law Dome (East Antarctica) snow pit, Ann. Glaciol., 35, 463-470, 2002.

Moraal, H., Muscheler, R., du Plessis, L., Kubik, P. W., Beer, J., McCracken, K. G., and McDonald, F. B.: ${ }^{10}$ Be concentration in the Ice Shelf of Queen Maude Land, Antarctica, S. Afr. J. Sci., 101, 299-301, 2005.

Moraal, H., Stoker, P., and Krüger, H.: Neutron monitor observations of the 2009 solar minimum, in: $31^{\text {st }}$ ICRC, Lodz, 1-4, 2009.

Morgan, V. I., Wookey, C. W., Li, J., van Ommen, T. D., Skinner, W., and Fitzpatrick, M. F.: Site information and initial results from deep ice drilling on Law Dome, Antarctica, J. Glaciol., 43, 3-10, 1997.

Mudelsee, M.: Estimating Pearson's Correlation Coefficient With Bootstrap Confidence Interval From Serially Dependent Time Series, Math. Geol., 35, 651-665, 2003.

Muscheler, R., Joos, F., Beer, J., Müller, S. A., Vonmoos, M., and Snowball, I.: Solar activity during the last $1000 \mathrm{yr}$ inferred from radionuclide records, Quaternary Sci. Rev., 26, 8297, doi:10.1016/j.quascirev.2006.07.012, 2007.

Nishiizumi, K., Imamura, M., Caffee, M. W., Southon, J. R., Finkel, R. C., and McAninch, J.: Absolute calibration of ${ }^{10}$ Be AMS standards, Nucl. Instrum. Meth. B, 258, 403-413, doi:10.1016/j.nimb.2007.01.297, 2007.
O'Brien, K. and Burke, G. D. P.: Calculated cosmic ray neutron monitor response to solar modulation of galactic cosmic rays., J. Geophys. Res., 78, 3013-3019, doi:10.1029/JA078i016p03013, 1973.

Palmer, A. S., van Ommen, T. D., Curran, M. A. J., Morgan, V., Souney, J. M., and Mayewski, P. A.: High-precision dating of volcanic events (A.D. 1301-1995) using ice cores from Law Dome, Antarctica, J. Geophys. Res., 106, 28089-28096, doi:10.1029/2001JD000330, 2001.

Pedro, J., van Ommen, T., Curran, M., Morgan, V., Smith, A., and McMorrow, A.: Evidence for climate modulation of the ${ }^{10} \mathrm{Be}$ solar activity proxy, J. Geophys. Res.-Atmos., 111, D21105, doi:10.1029/2005JD006764, 2006.

Pedro, J., Smith, A., Duldig, M., Kelkociuk, A., Simon, K., Curran, M., van Ommen, T., Fink, D., Morgan, V., and Galton-Fenzi, B.: ${ }^{10} \mathrm{Be}$ concentrations in snow at Law Dome Antarctica following the 29 October 2003 and 20 January 2005 Solar Cosmic Ray Events, in: Advances in Geosciences, edited by: Duldig, M., 14, Solar Terrestrial (2007), World Scientific Publishing Company, 2009.

Raisbeck, G. M., Yiou, F., Fruneau, M., Lieuvin, M., and Loiseaux, J. M.: Measurement of Be-10 in 1,000- and 5,000-year-old Antarctic ice, Nature, 275, 731-733, doi:10.1038/275731a0, 1978.

Raisbeck, G. M., Yiou, F., Fruneau, M., Loiseaux, J. M., Lieuvin, M., and Ravel, J. C.: Cosmogenic Be-10/Be-7 as a probe of atmospheric transport processes, Geophys. Res. Lett., 8, 10151018, 1981.

Raisbeck, G. M., Yiou, F., Jouzel, J., and Petit, J. R.: ${ }^{10}$ Be and $\delta{ }^{2} \mathrm{H}$ in Polar Ice Cores as a Probe of the Solar Variability's Influence on Climate, Royal Society of London Philosophical Transactions Series A, 330, 463-469, doi:10.1098/rsta.1990.0027, 1990.

Sanak, J., Lambert, G. and Ardouin, B.: Measurement of stratosphere-to-troposphere exchange in Antarctica by using short-lived cosmonuclides, Tellus B, 37B, 109-115, doi:10.1111/j.1600-0889.1985.tb00059.x, 1985.

Savoie, D. L., Prospero, J. M., Larsen, R. J., and Saltzman, E. S.: Nitrogen and sulfur species in aerosols at Mawson, Antarctica, and their relationship to natural radionuclides, J. Atmos. Chem., 14, 181-204, 1992.

Simon, K., Pedro, J., Smith, A., Child, D., and Fink, D.: Reprocessing of ${ }^{10} \mathrm{~B}$-contaminated ${ }^{10} \mathrm{Be}$ AMS targets, in: AMS-12 Conference, Wellington, New Zealand, 20-25 March, 2011.

Smith, A. M., Fink, D., Child, D., Levchenko, V. A., Morgan, V. I., Curran, M., Etheridge, D. M., and Elliott, G.: ${ }^{7} \mathrm{Be}$ and ${ }^{10} \mathrm{Be}$ concentrations in recent firn and ice at Law Dome, Antarctica, Nucl. Instrume. Methods B, 172, 847-855, 2000.

Steig, E. J., Polissar, P. J., Stuiver, M., Grootes, P. M., and Finkel, R. C.: Large amplitude solar modulation cycles of ${ }^{10} \mathrm{Be}$ in Antarctica: Implications for atmospheric mixing processes and interpretation of the ice core record, Geophys. Res. Lett., 23, 523-526, doi:10.1029/96GL00255, 1996.

Steinhilber, F., Beer, J., and Fröhlich, C.: Total solar irradiance during the Holocene, Geophys. Res. Lett., 36, L19704, doi:10.1029/2009GL040142, 2009.

Stohl, A. and Sodemann, H.: Characteristics of atmospheric transport into the Antarctic troposphere, J. Geophys. Res., 115, D02305, doi:10.1029/2009JD012536, 2010.

Usoskin, I. G., Alanko-Huotari, K., Kovaltsov, G. A., and Mursula, 
K.: Heliospheric modulation of cosmic rays: Monthly reconstruction for 1951-2004, Journal of Geophysical Research (Space Physics), 110, A12108, doi:10.1029/2005JA011250, phi values tabulated at: http://cosmicrays.oulu.fi/phi/phi.html, 2005.

van Ommen, T. D. and Morgan, V.: Calibrating the ice core paleothermometer using seasonality, J. Geophys. Res., 102, 93519358, doi:10.1029/96JD04014, 1997.

van Ommen, T. D. and Morgan, V.: Snowfall increase in coastal East Antarctica linked with southwest Western Australian drought, Nat. Geosci., 3, 267-272, doi:10.1038/ngeo761, 2010.

Vonmoos, M., Beer, J., and Muscheler, R.: Large variations in Holocene solar activity: Constraints from ${ }^{10} \mathrm{Be}$ in the Greenland Ice Core Project ice core, J. Geophys. Res.-Space, 111, A10105, doi:10.1029/2005JA011500, 2006.

Wagenbach, D.: Coastal Antarctica: Atmospheric chemical composition and atmospheric transport, in: NATO ASI Series, Series I, 43, Chemical exchange between the atmosphere and polar snow, edited by: Wolff, E. W. and Bales, R. C., 173-199, Spinger-Verlag, 1996.
Webber, W. R. and Higbie, P. R.: What Voyager cosmic ray data in the outer heliosphere tells us about ${ }^{10} \mathrm{Be}$ production in the Earth's polar atmosphere in the recent past, J. Geophys. Res.-Space, 115, A05102, doi:10.1029/2009JA014532, 2010.

Webber, W. R., Higbie, P. R., and McCracken, K. G.: Production of the cosmogenic isotopes ${ }^{3} \mathrm{H},{ }^{7} \mathrm{Be},{ }^{10} \mathrm{Be}$, and ${ }^{36} \mathrm{Cl}$ in the Earth's atmosphere by solar and galactic cosmic rays, J. Geophys. Res.Space, 112, A10106, doi:10.1029/2007JA012499, 2007.

Wolff, E. W.: The record of aerosol deposited species in ice cores and problems of interpretation, in: NATO ASI Series, Vol. I 43, Chemical Exchange Between the Atmosphere and Polar Snow, edited by: Wolff, E. and Bales, R., 1-17, Springer, 1996.

Yiou, F., Raisbeck, G. M., Baumgartner, S., Beer, J., Hammer, C., Johnsen, S., Jouzel, J., Kubik, P. W., Lestringuez, J., Stiévenard, M., Suter, M., and Yiou, P.: Beryllium 10 in the Greenland Ice Core Project ice core at Summit, Greenland, J. Geophys. Res., 102, 26783-26794, doi:10.1029/97JC01265, 1997. 